\title{
Pregnancy outcome in women treated for subclinical hypothyroidism detected in early gestation
}

\section{Raja Rajeswari C.*, Suman Paul, Madhusmita Nayak}

Department of Obstetrics and Gynecology, Lisie Hospital, Ernakulam, Kerala, India

Received: 13 December 2017

Accepted: 08 January 2018

\section{*Correspondence:}

Dr. Raja Rajeswari C.,

E-mail: rajeswaridr@yahoo.co.in

Copyright: () the author(s), publisher and licensee Medip Academy. This is an open-access article distributed under the terms of the Creative Commons Attribution Non-Commercial License, which permits unrestricted non-commercial use, distribution, and reproduction in any medium, provided the original work is properly cited.

\begin{abstract}
Background: Thyroid disorders are among the most common endocrine disorders in pregnancy. Objective of present study were to investigate the outcome of pregnancy in those women detected to have subclinical hypothyroidism in early gestation and to evaluate whether treatment of subclinical hypothyroidism reduces the adverse pregnancy outcome.

Methods: Pregnant women detected to have Subclinical hypothyroidism (TSH > 2.5- 6 mU/L and N Free T4) in the $1^{\text {st }}$ trimester were selected and randomly divided into 2 groups. One group received treatment with Thyroxine. They were followed up till delivery and outcome noted.

Results: The mean maternal age of both the group was 26 yrs. The gestational age at delivery and the newborn birth weight did not show any statistically significant difference. Antenatal complications like Gestational Diabetes, hypertension, small for gestation, and preterm were almost the same in both groups. There was significant increase in the primary caesarean rate in the treated group. No significant difference in the number of term vaginal delivery in both groups.

Conclusions: Treatment of women with $\mathrm{SCH}(\mathrm{TSH}<6 \mathrm{mU} / \mathrm{L})$ does not reduce the risk of adverse pregnancy outcome. Benefits of treatment need to be weighed against any potential risks.
\end{abstract}

Keywords: Gestational hypertension, Gestational diabetes mellitus, Subclinical hypothyroidism, Thyroxine

\section{INTRODUCTION}

Thyroid disorders are among the most common endocrine disorders in pregnancy. In India, about $13 \%$ of all pregnancies are affected by hypothyroidism. ${ }^{1}$ Subclinical hypothyroidism $(\mathrm{SCH})$ is detected in about $2.3 \%$ of pregnant women. ${ }^{2}$ It is defined as an elevated serum TSH level between 2.5 and $10 \mathrm{mU} / \mathrm{L}$ and a serum free T4 level that is within the normal lab and trimester specific reference ranges.

Causes of hypothyroidism include iodine deficiency, congenital, postoperative or ablative changes, viral thyroiditis, autoimmune thyroiditis. Thyroid peroxidise antibodies and thyroglobulin antibodies are detectable in a significant number of patients with hypothyroidism and subclinical hypothyroidism.

Signs and symptoms of $\mathrm{SCH}$ are variable; often asymptomatic. Mostly $\mathrm{SCH}$ is a laboratory diagnosis. Risk factors include personal or family history of thyroid dysfunction, advanced maternal age, diabetes, other autoimmune disorders, morbid obesity.

TSH levels are generally lower throughout pregnancy, especially during the first trimester when the hCG levels peak. The trimester specific reference range recommended by American Thyroid Association guidelines is $1^{\text {st }}$ Trimester TSH $0.1-2.5,2^{\text {nd }}$ trimester TSH $0.2-3,3^{\text {rd }}$ trimester TSH $0.3-3 .{ }^{3}$ No consensus has been 
reached about the need for universal thyroid screening and the treatment of subclinical hypothyroidism in pregnancy. ${ }^{4}$

$\mathrm{SCH}$ can lead to placental abruption, preterm labour, diabetes, gestational hypertension and neonatal complications like neurological deficits and respiratory distress syndrome. ${ }^{5-8}$ Currently there is no evidence that identification and treatment of $\mathrm{SCH}$ during pregnancy improve these outcomes. ${ }^{9}$

\section{METHODS}

Prospective randomized study conducted in a 650-bedded tertiary care centre. A total of 160 pregnant women detected to have subclinical hypothyroidism in their 1st trimester of pregnancy (TSH value $>2.5-6 \mathrm{mU} / \mathrm{L}$ ) were included in the study. Out of these 80 women received treatment with Thyroxine (Group A) and 80 were left untreated and acted as controls (Group B).

\section{Inclusion criteria}

- All pregnant women booked in our Antenatal clinic detected to have subclinical hypothyroidism in 1 st trimester of pregnancy

- Singleton pregnancy.

\section{Exclusion criteria}

- Pregnant women with overt hypothyroidism

- Pregnant women with subclinical hypothyroidism having TSH $>6 \mathrm{mU} / \mathrm{L}$ but $<10 \mathrm{mU} / \mathrm{L}$

- Pregnant women with medical complications like chronic hypertension, overt diabetes

- Multiple pregnancy.

The selected women and their relatives were informed about the study in detail and consent obtained. The treatment group [Group A] received 12.5-25 mcg thyroxine daily. They were followed up till delivery and the outcome compared in both groups. The recorded data were statistically analysed.

\section{RESULTS}

The mean age of both groups was 26 yrs, the $p$ value was $>0.05$ indicating that the two groups are comparable.

Table 1: Maternal age.

\begin{tabular}{|lll|}
\hline Age (years) & Group A & Group B \\
\hline$\leq 20$ & 3 & 10 \\
\hline $21-30$ & 65 & 59 \\
$>30$ & 12 & 11 \\
\hline
\end{tabular}

In the obstetric score, most of the women were primi gravida [G1] in both groups. There is significant difference seen in the number of two groups regarding women with previous abortion (G2A1, G3A2) $\left(\mathrm{X}^{2}=\right.$
4.765, $\mathrm{df}=1, \mathrm{p}=<0.05)$. Number of multi gravida were also comparable.

Table 2: Obstetric score.

\begin{tabular}{|lll|}
\hline GPLA & Group A & Group B \\
\hline G1 & 43 & 49 \\
G2A1, G3A2 & 13 & 4 \\
\hline G2P1L1 and above & 24 & 27 \\
\hline
\end{tabular}

Antenatal complications like Gestational Diabetes, Gestational Hypertension, small for gestation/ Intra uterine growth restriction and preterm delivery were observed almost equally in both case and control groups.

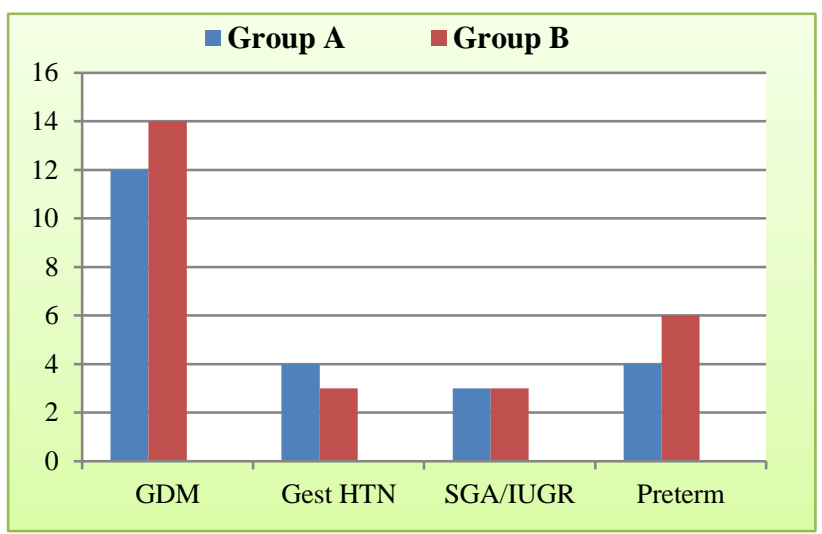

Figure 1: Antenatal complication.

In the mode of delivery, 46 women in the treated group and 53 women in the control group delivered vaginally at term and there was no significant difference $\left(X^{2}=0.495\right.$, $\mathrm{df}=1, \mathrm{p}>0.05)$. In the primary caesarean rate significant difference was observed in both groups $\left(\mathrm{X}^{2}=5.828\right.$, $\mathrm{df}=1, \mathrm{p}<0.05)$. The number of repeat caesarean section and preterm vaginal delivery were comparable in the two groups.

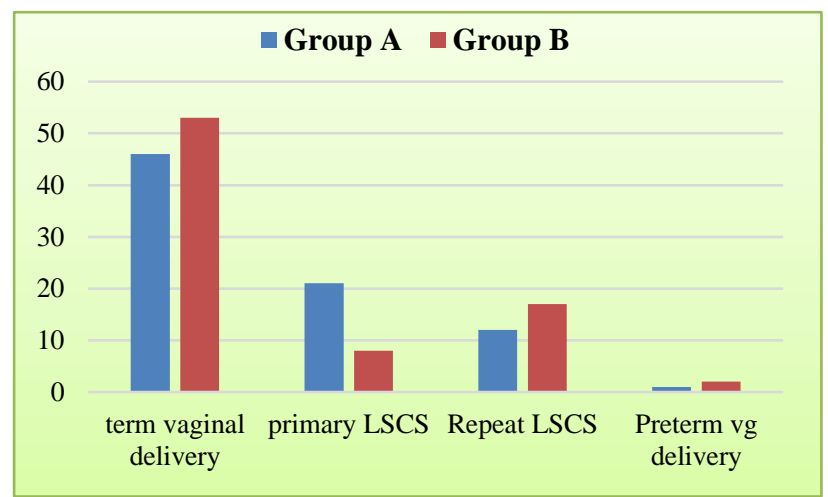

Figure 2: Mode of delivery.

Regarding the gestational age at delivery, in the $\leq 34$ weeks group, 3 women were from the treated group and only one from the control group. Majority of women delivered after 37 weeks and the numbers were comparable in both the groups. 
Table 3: Gestational age at delivery.

\begin{tabular}{|lll|}
\hline Gestational age (weeks) & Group A & Group B \\
$\leq 34$ & 3 & 1 \\
\hline$>34$ to $<37$ & 1 & 5 \\
$\geq 37$ & 76 & 74 \\
\hline
\end{tabular}

Majority of newborns in both groups had birth weight in the range of $>2.5$ to $<3.5 \mathrm{Kg}$. The mean birth weight in the treated group was $2.86 \mathrm{Kg}$ and in the control group was 2.99 and there was no significant difference $(\mathrm{t}=1.384, \mathrm{df}=158, \mathrm{p}$ value $=>0.05)$.

Table 4: Birth weight.

\begin{tabular}{|lll|}
\hline Birth weight $(\mathrm{Kg})$ & Group A & Group B \\
\hline$\leq 2.5$ & 13 & 13 \\
\hline$>2.5$ to $<3.5$ & 62 & 59 \\
\hline$\geq 3.5$ & 5 & 8 \\
\hline
\end{tabular}

\section{DISCUSSION}

TSH levels are generally lower throughout the pregnancy, especially during the $1^{\text {st }}$ trimester when HCG levels peak. Subclinical hypothyroidism $(\mathrm{SCH})$ is found to have a high risk for placental abruption, preterm labour, Gestational hypertension, Diabetes and neuro developmental delay in the baby. Hence earlier studies emphasised the treatment for SCH in early pregnancy. ${ }^{5,10}$ In the present study, pregnant women with $\mathrm{SCH}$ and TSH level $<6 \mathrm{mU} / \mathrm{L}$ were selected, and half were treated with Thyroxine. They were evaluated for development of complications and was found that both the groups had almost equal number of complication. This was comparable to the study by Cleary- Goldman et al done as part of FASTER trial. ${ }^{10}$ They did not find any increased risk for Pre-eclampsia, placental abruption, preterm delivery, gestational diabetes or fetal death. Similar observation was also made by Negro et al. ${ }^{11}$ This is in contrast to the observation made by Casey BM and associates. ${ }^{5}$ They did a prospective study on pregnancy complications with $\mathrm{SCH}$ and found significant increase in placental abruption, preterm labour and neonatal respiratory distress.

Table 5: Comparison of mode of delivery.

\begin{tabular}{|llll|}
\hline Mode of delivery & $\mathbf{X}^{2}$ & Df & P value \\
\hline Term vaginal delivery & 0.495 & 1 & $>0.05$ \\
\hline Primary LSCS & 5.828 & 1 & $<0.05$ \\
\hline Repeat LSCS & 0.862 & 1 & $>0.05$ \\
\hline
\end{tabular}

The mean age of both the groups and the gestational age at delivery was comparable in our study. In the Obstetric score, significant number of women with previous abortion were in the Group $\mathrm{A}\left(\mathrm{X}^{2}=4.765, \mathrm{df}=1, \mathrm{p}<0.05\right)$ and 3 out of 13 developed GDM.

Among the mode of delivery in the present study, statistically significant difference was found in the primary caesarean rate. There was no significant difference in the average birth weight of new-borns in both the groups.

Table 6: Comparison of neonatal birth weight.

\begin{tabular}{|lllllll} 
Group & $\begin{array}{l}\text { Sample } \\
\text { sive }\end{array}$ & $\begin{array}{l}\text { Mean } \\
(\mathrm{kg})\end{array}$ & SD & T & Df & $\begin{array}{l}\text { P } \\
\text { value }\end{array}$ \\
A & 80 & 2.86 & 0.5967 & 1.384 & 158 & $>0.05$ \\
\hline B & 80 & 2.99 & 0.5915 & & & \\
\hline
\end{tabular}

Present study demonstrated a good neonatal outcome in both the groups. This is comparable to the study of Mannistol and colleagues, who evaluated the relationship between pregnancy outcome and thyroid function at 12 weeks of gestation 12. They found no adverse consequence on perinatal mortality.

Experts in 2011, opine that if subclinical hypothyroidism is diagnosed either by symptoms or by risk factors, insufficient evidence exists either for or against a recommendation for treatment with a low dose of levothyroxine. ${ }^{4}$ They did not recommend Universal screening of all pregnant women for hypothyroidism. Brian M Casey and associates 13 found that although $\mathrm{SCH}$ has been associated with severe obstetric complications there has been no direct evidence that Levothyroxine therapy reduces these risks. Similar observation was made in present study. The development of GDM, Gestational hypertension, small for gestation and preterm delivery in both the groups were comparable. None of them had placental abruption.

\section{CONCLUSION}

Subclinical hypothyroidism is one of the commonest thyroid disorders in pregnancy. In pregnant women with $\mathrm{SCH}$ (TSH > 2.5-6 mU/L and Normal T4 level), treatment with thyroxine does not have any association in reducing the incidence of preterm labour, Gestational Diabetes or Hypertension. Neonatal outcome was normal in both the groups. Overall maternal and neonatal outcome is comparable in both the groups. Benefits of treatment need to be weighed against any potential risks. Over treatment of subclinical hypothyroidism can cause iatrogenic hyperthyroidism.

\section{Funding: No funding sources}

Conflict of interest: None declared

Ethical approval: The study was approved by the Institutional Ethics Committee

\section{REFERENCES}

1. Dhanwal DK, Bajaj S, Rajput R, Subramaniam KA, Chowdhury S, Bhandari R et al. Prevalence of hypothyroidism in pregnancy: An epidemiological study from 11 cities in 9 states of India. Indian $\mathbf{J}$ Endocrinol Metab. 2016;20(3):387-90. 
2. Radha KR, Sugunan N, Resmy CR. Cross sectional study in a rural tertiary care centre in Kerala, India, do we need to screen and treat pregnant women for Subclinical hypothyroidism?. IJRCOG. 2017;6(3):781-6.

3. Stagnaro-Green A, Abalovich M, Alexander E, Azizi F, Mestman J, Negro R et al. Guidelines of the American Thyroid Association for the diagnosis and management of thyroid disease during pregnancy and postpartum. Thyroid. 2011 Oct;21(10):1081-125.

4. Sullivan SA. Subclinical hypothyroidism: Identification and treatment in pregnancy. Contemporary Ob/Gyn Womens Health. 2011.

5. Casey BM, Dashe JS, Wells CE, McIntire DD, Byrd W, Leveno KJ, Cunningham FG. Subclinical hypothyroidism and pregnancy outcomes. Obstet Gynecol. 2005 Feb;105(2):239-45.

6. Wilson KL, Casey BM, McIntire DD, Halvorson LM, Cunningham FG. Subclinical thyroid disease and the incidence of hypertension in pregnancy. Obstet Gynecol. 2012 Feb;119(2, Part 1):315-20.

7. Tudela CM, Casey BM, McIntire DD, Cunningham FG. Relationship of subclinical thyroid disease to the incidence of gestational diabetes. Obstet Gynecol. 2012 May;119(5):983-8.

8. Nelson DB, Casey BM, McIntire DD, Cunningham FG. Subsequent pregnancy outcomes in women previously diagnosed with subclinical hypothyroidism. Am J Perinatol. 2014 Jan;31(01):077-84.
9. Cunningham FG, Leveno KJ, Bloom SL, Spong CY, Dashe JS, Hoffman BL et al. Williams Obstetrics. Endocrine disorders. 24 ${ }^{\text {th }}$ ed. McGraw-Hill Global Education Holdings, LLC;2014:1154-5.

10. Cleary-Goldman J, Malone FD, Lambert-Messerlian G, Sullivan L, Canick J, Porter TF et al. Maternal thyroid hypofunction and pregnancy outcome. Obstetrics and gynecology. 2008 Jul;112(1):85.

11. Negro R, Schwartz A, Gismondi R, Tinelli A, Mangieri T, Stagnaro-Green A. Universal screening versus case finding for detection and treatment of thyroid hormonal dysfunction during pregnancy. The J Clin Endocrinol Metab. 2010 Apr;95(4):1699-707.

12. Männistö $T$, Vääräsmäki $M$, Pouta $A$, Hartikainen AL, Ruokonen A, Surcel $\mathrm{HM}$ et al. Perinatal outcome of children born to mothers with thyroid dysfunction or antibodies: a prospective populationbased cohort study. J Clin Endocrinol Metab. 2009 Mar 1;94(3):772-9.

13. Casey BM, Thom EA, Peaceman AM, Varner MW, Sorokin Y, Hirtz DG et al. Treatment of subclinical hypothyroidism or hypothyroxinemia in pregnancy. N Engl J Med. 2017 Mar 2;376(9):815-25.

Cite this article as: Rajeswari RC, Paul S, Nayak M. Pregnancy outcome in women treated for subclinical hypothyroidism detected in early gestation. Int $\mathrm{J}$ Reprod Contracept Obstet Gynecol 2018;7:685-8. 